\title{
Immunolocalization of steroidogenic enzymes P450scc, 3ßHSD, P450c17 and P450arom in the corpus luteum of the Hokkaido brown bear (Ursus arctos yesoensis) in relation to delayed implantation
}

\author{
T. Tsubota ${ }^{1,2}$, H. Nitta ${ }^{1, *}$, Y. Osawa ${ }^{3}$, J. I. Mason ${ }^{4}$, I. Kita ${ }^{2}$, T. Tiba ${ }^{2}$ \\ and J. M. Bahr ${ }^{1, \dagger}$ \\ ${ }^{1}$ Department of Animal Sciences, University of Illinois, Urbana, IL 61801, USA ${ }^{2}$ Laboratory of \\ Theriogenology, Faculty of Agriculture, Gifu University, Gifu, Japan; ${ }^{3}$ Endocrine Biochemistry \\ Department, Medical Foundation of Buffalo Research Institute, Buffalo, NX, USA; and ${ }^{4}$ Green Center for \\ Reproductive Biology Sciences, University of Texas Southwestern Medical Center, Dallas, TX, USA
}

\begin{abstract}
The objective was the immunocytochemical localization of steroidogenic enzymes in the corpus luteum of Hokkaido brown bears during the period of delayed implantation. Cholesterol side-chain cleavage cytochrome P450 (P450scc), 3ß-hydroxysteroid dehydro-

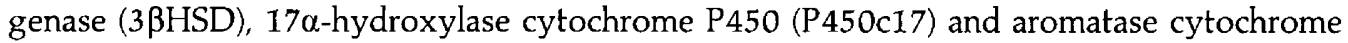
P450 (P450arom) were localized as biosynthetic sites of pregnenolone, progesterone, androgens, and oestrogens, respectively. Ovaries containing corpora lutea were obtained from three mature bears during the expected delayed implantation period and ovarian sections were immunostained by the avidin-biotin-peroxidase complex method using polyclonal antibodies generated against steroidogenic enzymes of mammalian origin. P450scc and 3BHSD were localized in all luteal cells, whereas P450c17 $(0.4-5.1 \%$ of 1000 cells) and P450arom (7.1-11.2\% of 1000 cells) were localized in only a few luteal cells. These data suggest that luteal cells contain steroidogenic enzymes required for progesterone synthesis but also have a minimum capability for synthesizing androgen and oestrogen during the delayed implantation period in Hokkaido brown bears.
\end{abstract}

\section{Introduction}

Hokkaido brown bears (Ursus arctos yesoensis) have a mating season from late April to early July (Tsubota et al., 1985). After mating, there is a $160-170$ day period of embryonic diapause (Tsubota et al., 1987) and during this period, unimplanted embryos are present as blastocysts in the uterine lumen (Tsubota et al., 1991a; Tsubota and Kanagawa, 1993). Implantation is considered to occur in late November or early December. The period of fetal growth is approximately 60 days based on ultrasonographic diagnosis (Tsubota et al., 1987) and parturition occurs between mid-January and early February (Sumiyoshi, 1973).

Progesterone concentrations in peripheral blood may aid the determination of the stage of the luteal phase in pregnant bears. Serum progesterone concentrations are not detectable before the mating season, are detectable during the period of delayed implantation and exhibit a sharp increase at the time of implantation (Foresman and Daniel, 1983; Tsubota et al., 1987; Hellgren et al., 1991). Corpora lutea from Hokkaido brown bears (Tsubota and Kanagawa, 1993) and American black bears

*Present address: Department of Veterinary Bioscience, University of Illinois, Urbana, IL 61801, USA.

${ }^{\dagger}$ Correspondence.

Received 5 October 1993.
(Wimsatt, 1963), obtained during the delayed implantation period, contain vacuoles or numerous granules in their cytoplasm, suggesting that progesterone is being synthesized. Although these latter studies suggest that the corpus luteum is a source of progesterone, it has not been directly determined whether the corpus luteum synthesizes progesterone and other steroids during the period of delayed implantation in bears.

The objective of this study was to localize the steroidogenic enzymes required to convert steroid substrates to progestins, androgens and oestrogens in the corpus luteum during the period of delayed implantation in Hokkaido brown bears.

\section{Materials and Methods}

\section{Immunocytochemistry}

Ovaries containing corpora lutea were removed from three adult female Hokkaido brown bears legally killed by hunters in November in Hokkaido, Japan. After the ovaries were fixed in $4 \%$ formaldehyde solution, they were dehydrated with graded concentrations of ethanol and embedded in paraffin wax. Sections, $5 \mu \mathrm{m}$ thick, were placed on poly-L-lysine coated glass slides (Poly-prep ${ }^{\mathrm{TM}}$ slides, Sigma, St Louis, MO). The sections were deparaffinized with toluene and immunostained for steroidogenic enzymes by an avidin-biotin-peroxidase 

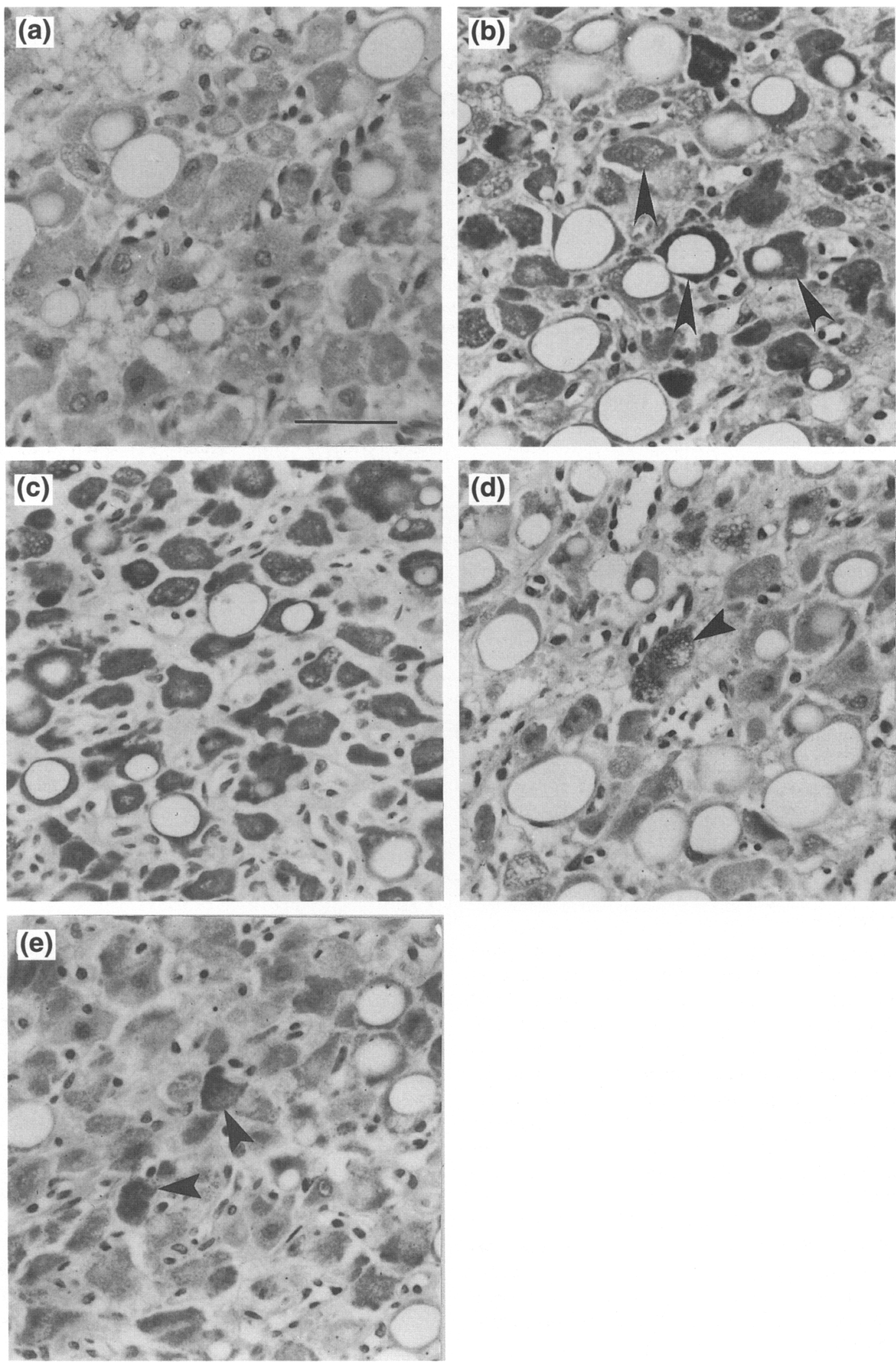

Fig. 1. Sections of corpora lutea from Hokkaido brown bears during the delayed implantation period. (a) Control incubated with normal rabbit serum in place of a primary antibody. (b) Immunostaining for P450scc. All luteal cells were positively immunostained (arrowheads). (c) Immunostaining for $3 \beta \mathrm{HSD}$. All luteal cells were positively immunostained. (d) Immunostaining for P450c17. A few luteal cells (arrowheads) were positively immunostained. (e) Immunostaining for P450arom. A few cells (arrowheads) were positively immunostained. All sections were negatively immunostained with haematoxylin as a counterstain. Scale bar represents $50 \mu \mathrm{m}$. 
Table 1. 17 $\alpha$-Hydroxylase cytochrome $\mathrm{P} 450$ ( $\mathrm{P} 450 \mathrm{c} 17)$ and aromatase cytochrome $\mathrm{P} 450$ ( $\mathrm{P} 450 \mathrm{arom}$ ) immunostaining and the mean size $( \pm \mathrm{SD})$ of 50 luteal cells from Hokkaido brown bears

\begin{tabular}{|c|c|c|c|c|c|c|c|c|}
\hline \multirow[b]{3}{*}{ Bear number } & \multicolumn{4}{|c|}{ P450c17 } & \multicolumn{4}{|c|}{ P450arom } \\
\hline & \multirow{2}{*}{$\begin{array}{c}\text { Percentage positive } \\
\text { per } \\
1000 \text { cells }\end{array}$} & \multicolumn{3}{|c|}{ Cell size $(\mu \mathrm{m})$} & \multirow{2}{*}{$\begin{array}{c}\text { Percentage positive } \\
\text { per } \\
1000 \text { cells }\end{array}$} & \multicolumn{3}{|c|}{ Cell size $(\mu \mathrm{m})$} \\
\hline & & Positive & Negative & $P$ & & Positive & Negative & $P$ \\
\hline 1 & 5.1 & $22.0 \pm 4.9$ & $27.3 \pm 5.4$ & $<0.001$ & 7.1 & $19.5 \pm 3.8$ & $25.8 \pm 4.5$ & $<0.001$ \\
\hline 2 & 1.2 & $17.4 \pm 2.4$ & $28.7 \pm 4.6$ & $<0.001$ & 11.2 & $26.6 \pm 4.1$ & $27.1 \pm 3.5$ & NS \\
\hline 3 & 0.4 & — $^{*}$ & $\ldots$ & & 10.6 & $21.8 \pm 3.5$ & $23.8 \pm 2.8$ & $<0.01$ \\
\hline
\end{tabular}

*Luteal cells with P450c17 immunostaining in Bear 3 were not measured because there were too few positive cells. NS: not significant.

complex method with a Rabbit ExtrAvidin ${ }^{\mathrm{TM}}$ staining kit (Sigma). Sections were treated with $10 \%$ normal goat serum in PBS before incubation with the primary antiserum for reducing background. Polyclonal antisera raised in rabbits were used: anti-cholesterol side-chain cleavage cytochrome P450 (P450scc) against bovine adrenal P450scc (Anakwe and Payne, 1987), anti-3 $\beta$-hydroxysteroid dehydrogenase (3ßHSD) against

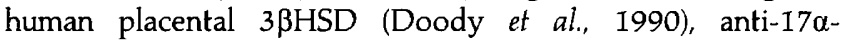
hydroxylase cytochrome $\mathrm{P} 450$ (P450c17) against porcine testicular P450c17 (Hales et al., 1987) and anti-aromatase cytochrome P450 (P450arom) against human placental P450arom (Kitawaki et al., 1989) for immunolocalization of pregnenolone-, progesterone-, androgen- and oestrogenproducing cells, respectively. Control sections were treated with the same concentration (1:500) of normal rabbit serum instead of the primary antiserum. Staining was obtained by treatment with 3,3'-diaminobenzidine (Sigma) solution $(20 \mathrm{mg}$ (100 ml) ${ }^{-1}$ Tris buffer plus $5 \mu \mathrm{H}_{2} \mathrm{O}_{2}$ ). Sections were counterstained with haematoxylin solution (Sigma) to correlate immunostaining with morphology of the ovary.

\section{Measurement of cell size}

The size of fifty luteal cells, with positive and negative immunostaining for P450c17 and P450arom, was measured using an Olympus photomicroscope with a $\times 40$ objective and a light tube through which an LED cursor was viewed. The movable cursor dot (approximately $0.1 \mu \mathrm{m}$ in diameter) was viewed with the specimen for measurement of diameter. Jandel Scientific Sigma Scan ${ }^{\mathbb{B}}$ Image Analysis software (Jandel Scientific, Corte Madera, CA) and a Numonics Graphics Digitizer (Numonicus Corporation, Montgomeryville, PA) were used for processing the measurements. The repeatability of measurements, expressed as the coefficient of variation $(\mathrm{CV})$ for ten measurements was $0.74 \%$ at $10 \mu \mathrm{m}$ and $5.8 \%$ at $0.7 \mu \mathrm{m}$. The minimum resolvable distance was $0.073 \mu \mathrm{m}$. The size was expressed by length $\times$ width. Luteal cells with P450c17immunostaining in Bear 3 were not measured because there were insufficient positive cells. Statistical analysis was carried out by Student's $t$ test.

\section{Results}

All ovaries contained corpora lutea, primary and atretic follicles and interstitial cells. The corpora lutea contained a septum of connective tissue and luteal cells were arranged radially around the septum. Corpora lutea were judged to be steroidogenically active because of the marked vacuolation in the cytoplasm of luteal cells as described by Tsubota and Kanagawa (1993).

Control sections were negatively stained except for the counterstaining of nuclei with haematoxylin (Fig. Ia). P450scc was present in all luteal cells with a range of staining intensity among individual cells (Fig. Ib). 3ßHSD was immunolocalized in all luteal cells, in a similar way to P450scc (Fig. Ic). The entire cytoplasm, except for the area of vacuoles, contained positively immunostained P450scc- and 3BHSD-cells. A few cells positively immunostained for $\mathrm{P} 450 \mathrm{c} 17$ were present (Bear 1: $5.1 \%$ of 1000 cells; Bear 2: $1.2 \%$ of 1000 cells; Bear 3: $0.4 \%$ of 1000 cells) especially in the outer area of the corpus luteum (Fig. Id). A few luteal cells (Bear 1: $7.1 \%$ of 1000 cells; Bear 2: $11.2 \%$ of 1000 cells; Bear 3: $10.6 \%$ of 1000 cells) were sporadically immunostained for P450arom (Fig. Ie).

Positively immunostained cells were significantly smaller than negatively immunostained cells for P450c17 of Bear 1 $(P<0.001)$ and Bear $2(P<0.001)$ and for P450arom of Bear 1 $(P<0.001)$ and Bear $3(P<0.01)$ (Table 1$)$.

\section{Discussion}

In the study reported here, we were unable to determine whether unimplanted embryos were present in the uterine lumen because the uteri were fixed in formaldehyde solution before they were flushed for the recovery of embryos. It is assumed, however, that the bears with corpora lutea on their ovaries had unimplanted embryos in the uterine lumen because: (i) these samples were collected at the time delayed implantation usually occurs (November) (Tsubota et al., 1991b; Tsubota and Kanagawa, 1993); (ii) luteal cells contain large vacuoles suggesting that these cells were steroidogenically active (Sinha and Mead, 1975; Wimsatt, 1963) and (iii) the uterine glands had numerous tall epithelial cells, which are indicative of delayed implantation (Tsubota and Kanagawa, 1993). In particular, the morphology of luteal cells and the uterine endometrium corresponded to the previous report by Tsubota and Kanagawa (1993) which strongly supports the assumption that the bears in the study reported here were undergoing delayed implantation.

This immunocytochemical study showed that all luteal cells of Hokkaido brown bears contained P450scc and $3 \beta \mathrm{HSD}$ 
during the delayed implantation period. P450scc and $3 \beta \mathrm{HSD}$ were located in the area of abundant vacuoles that probably contained lipid droplets as the steroid substrate (Wimsatt, 1963; Sinha and Mead, 1975; Tsubota and Kanagawa, 1993). P450scc, which converts cholesterol to pregnenolone in the mitochondria of luteal cells, is a rate-limiting enzyme for luteal steroidogenesis (Carr, 1992). 33HSD converts pregnenolone to progesterone via the $\Delta^{4}$ steroidogenic pathway. Hence, our data suggest that, during the period of delayed implantation, corpora lutea of Hokkaido brown bears synthesize progesterone from cholesterol using these two enzymes.

Previous studies (Tsubota et al., 1987, 1991b) on the serum progesterone profile of Hokkaido brown bears, during the preimplantation and implantation periods indicated that a relatively high concentration of serum progesterone was present after mating. This was followed by a gradual increase until late November or early December, when a sharp increase occurred, suggesting that implantation had taken place. We conclude that the relatively high concentration of peripheral progesterone during delayed implantation is due to the production of this hormone by the corpus luteum. Production of progesterone by the corpus luteum of Hokkaido brown bears during this period is similar to that reported for western spotted skunks (Ravindra et al., 1984), ferrets (Mead and Swannack, 1980; Kintner and Mead, 1983) and badgers (Fevold and Wright, 1969). However, the possibility that, in bears, the placenta is responsible for progesterone synthesis, as reported in grey seals (Hobson and Boyd, 1984), still remains.

In this study, only a few luteal cells contained P450c17 and P450arom, suggesting that the corpus luteum has little capability for synthesizing androgen and oestrogen. Cells that were positive for $\mathrm{P} 450 \mathrm{c} 17$ and $\mathrm{P} 450$ arom were smaller than cells that lacked the enzymes. There are two possible explanations for this observation: (i) one steroidogenic cell population contains the two steroidogenic enzymes, and these cells synthesize both androgen and oestrogen, or (ii) the two enzymes are contained in two separate cell populations which means that each cell population has the capability for synthesizing either androgen or oestrogen but not both. The present study supports the latter hypothesis because the percentage of the luteal cell population positively immunostained for P450arom $(7.1-11.2 \%)$ was greater than for P450c17 $(0.4-5.1 \%)$, and there was a difference in the distribution of the cell population immunostaining for P450c17 and P450arom; the cells that contained P450c17 were distributed in the outer region of the corpus luteum, whereas P450arom-positive cells were dispersed throughout the corpus luteum.

Corpora lutea of many mammals contain two distinct steroidogenic cell populations commonly called small and large luteal cells. In sheep and cattle, the large and small luteal cells originate from granulosa and theca interna cells, respectively (Donaldson and Hansel, 1965; O'Shea et al., 1980; Alila and Hansel, 1984). However, in carnivores, only one type of luteal cell, presumably derived from granulosa cells, has been reported (Mossman and Duke, 1973). Joseph and Mead (1988) noted that luteal cells of ferrets were presumed to be from granulosa cells, even though large and small luteal cells were observed. In humans, the corpus luteum is composed of two cell populations, granulosa-luteal cells which contain $\mathrm{P} 450 \mathrm{scc}$ and $3 \beta \mathrm{HSD}$, plus $\mathrm{P} 450$ arom in some cells, and theca-luteal cells which contain P450scc and $3 \beta \mathrm{HSD}$, plus $\mathrm{P} 450 \mathrm{c} 17$, in some cells (Carr, 1992). The results of the study reported here suggest that the distribution of steroidogenic cells of the corpus luteum of bears is similar to that in the human corpus luteum. The corpus luteum of bears appears to have two kinds of steroidogenic cell populations, theca-luteal cells and granulosaluteal cells, which synthesize progesterone plus small amounts of androgen and oestrogen, respectively.

This immunocytochemical study indicates that during the period of delayed implantation in bears corpora lutea are a source of progesterone which may play an important role in the maintenance of unimplanted embryos. Further studies are required to evaluate the interaction between progesterone and other steroids, such as androgens and oestrogens, as well as the physiological role of progesterone during the pre- and postimplantation period. Furthermore, it is necessary to consider the possible involvement of factor(s) that in conjunction with progesterone (Mead et al., 1988) induce(s) blastocyst implantation when delayed implantation is terminated.

The authors thank K. Kaji, T. Mano, H. Kanagawa and M. Suzuki for help with the collection of specimens. They are also grateful to A. H. Payne for kindly supplying P450scc and P450c17 antisera and to $\mathrm{R}$. Hess for giving technical support for observations by microscope. This study was partially funded by the Nature Preservation Division of the Hokkaido Government, Japanese Society for the Promotion of Science (T. Tsubota), NIH-HD04945 (Y. Osawa), NIH-AG08175 (J. I. Mason) and USDA-89-01666 (J. M. Bahr).

\section{References}

Alila HW and Hansel W (1984) Origin of different cell types in the bovine corpus luteum as characterized by specific monoclonal antibodies Biology of Reproduction 31 1015-1025

Anakwe OO and Payne AH (1987) Noncoordinate regulation of de novo synthesis of cytochrome P-450cholesterol side-chain cleavage and cytochrome P-450 17 $\alpha$-hydroxylase/c17-20lyase in mouse Leydig cell cultures: relation to steroid production Molecular Endocrinology 1 596-603

Carr BR (1992) Disorders of the ovary and female reproductive tract. In Williams Textbook of Endocrinology 8th Edition pp 733-798 Eds ID Wilson and DW Foster. Saunders, Philadelphia

Donaldson L and Hansel W (1965) Histological study of bovine corpora lutea Journal of Dairy Science 48 905-909

Doody KM, Carr BR, Rainey WE, Byrd W, Murry BA, Strickler RC, Thomas JI and Mason JI (1990) 3 3 -Hydroxysteroid dehydrogenase/isomerase in the fetal zone and neocortex of the human fetal adrenal gland Endocrinology 126 2487-2492

Fevold RH and Wright PL (1969) Steroid metabolism by badger (Taxidea taxus) ovarian tissue homogenates General and Comparative Endocrinology $1360-67$

Foresman KR and Daniel JC Jr (1983) Plasma progesterone concentrations in pregnant and non-pregnant black bears Journal of Reproduction and Fertility $68235-239$

Hales DB, Sha L and Payne AH (1987) Testosterone inhibits cAMP-induced de novo synthesis of Leydig cell cytochrome P-45017 $\alpha$ by an androgen receptor-mediated mechanism Journal of Biological Chemistry 262 1120011206

Hellgren EC, Vaughan MR, Gwazdauskas FC, Williams B, Scanlon PF and Kirkpatrick RL (1991) Endocrine and electrophoretic profiles during pregnancy and nonpregnancy in captive female black bears Canadian Journal of Zoology $69892-898$

Hobson BM and Boyd IL (1984) Gonadotrophin and progesterone concentrations in placentae of grey seals (Halichoerus grypus) Journal of Reproduction and Fertility 72 521-528

Joseph MM and Mead RA (1988) Size distribution of ferret luteal cells during pregnancy Biology of Reproduction 39 1159-1169 
Kintner PJ and Mead RA (1983) Steroid metabolism in the corpus luteum of the ferret Biology of Reproduction 29 1121-1127

Kitawaki J, Yoshida N and Osawa Y (1989) An enzyme-linked immunosorbent assay for quantitation of aromatase cytochrome P-450 Endocrinology $\mathbf{1 2 4}$ $1417-1423$

Mead RA and Swannack A (1980) Aromatase activity in corpora lutea of the ferret Biology of Reproduction 22 560-565

Mead RA, Joseph MM, Neirinckx S and Berria M (1988) Partial characterization of a luteal factor that induces implantation in the ferret Biology of Reproduction 38 798-803

Mossman HW and Duke KL (1973) Comparative Morphology of the Mammalian Ovary. University of Wisconsin Press, Madison

O'Shea JD, Cran DG and Hay MF (1980) Fate of the theca interna following ovulation in the ewe Cell and Tissue Research $210305-319$

Ravindra R, Bhatia K and Mead RA (1984) Steroid metabolism in corpora lutea of the western spotted skunk (Spilogale putorius latifrons) Journal of Reproduction and Fertility 72 495-502

Sinha AA and Mead RA (1975) Ultrastructural changes in granulosa lutein cells and progesterone levels during preimplantation, implantation, and early placentation in the western spotted skunk Cell and Tissue Research 164 179-192

Sumiyoshi T (1973) Breeding records of Hokkaido brown bear in the Noboribetsu Bear Park Joumal of Japanese Association of Zoo Gardens and Aquariums XV 65-67 (in Japanese)
Tsubota T and Kanagawa H (1993) Morphological characteristics of the ovary, uterus and embryo during the delayed implantation period in the Hokkaido brown bear (Ursus arctos yesoensis) Journal of Reproduction and Development 39 325-331

Tsubota T, Kanagawa H, Takahashi K, Yasue T and Fukunaga S (1985) Observation of sexual behavior under captive conditions in Hokkaido brown bears Japanese Journal of Animal Reproduction 31 203-210 (in Japanese with English summary)

Tsubota T, Takahashi $Y$ and Kanagawa $H$ (1987) Changes in serum progesterone levels and growth of fetuses in Hokkaido brown bear International Conference of Bear Research and Management 7 355-358

Tsubota T, Takahashi Y, Kanagawa H and Gohda K (1991a) Embryo recovery during delayed implantation in the captive Hokkaido brown bear, Ursus arctos yesoensis Journal of Veterinary Medical Science 53 141-142

Tsubota T, Kanagawa H, Yamamoto K, Mano T, Yamanaka M, Kita I and Tiba T (1991b) Serum progesterone concentrations using P-EIA kit in captive and free-ranging Hokkaido brown bears, Ursus arctos yesoensis Journal of Veterinary Medical Science 54 1-5

Wimsatt WA (1963) Delayed implantation in the Ursidae, with particular reference to the black bear. In Delayed Implantation pp 49-86 Ed. AC Enders. University of Chicago Press, Chicago 